\title{
"Development Of Primary Health Care Based On District Health System Strategy In Egypt"
}

\author{
Eltobgy A. ${ }^{1}$, El-Henawy A. ${ }^{2}$, El-Moselhy E . ${ }^{1}$, and Osman A. ${ }^{1}$ \\ ${ }^{1}$ Community Medicine Department, Faculty of Medicine, Al-Azhar University, Egypt. \\ ${ }^{2}$ Urban Health Department, Ministry of Health and Population, Egypt
}

\begin{abstract}
The study aimed to improve the qualitative and quantitative aspects of primary health care (PHC) services within the context of the District Health System (DHS) approach in Egypt. A cross-sectional analytical research design was chosen to investigate the current research problem. The study samples included 9 health districts, 35 district hospitals and 201 primary health care facilities chosen randomly from eight governorates. The results revealed that the sampled districts (management level) are suffering from many administrative and technical problems. Analysis of district hospitals and PHC units' data showed that they have a severe defect in regarding to most of the studied essential elements. The researchers concluded that the concept of DHS based on PHC as proposed by the WHO is not very clear to the majority of directors but a very well infrastructure is present allover Egypt that will help in the process of system development and institution to a great extent if properly planned and organized.
\end{abstract}

\section{Introduction:}

Governmental health care systems are normally integrated into the national administration, thus being characterized by the centralized organizational structures. Three levels usually describe the providing structures. The Primary Health Care (PHC) level comprises basic promotive, preventive and curative services. The secondary care level stands for referral hospitals with broad based curative services. Specialized services with high standards can be found in national hospitals on the tertiary care level. The paradigm of PHC forwarded different strategies e.g. establishment of community based health care initiatives. These efforts turned out to be rather short lived due to the lack of a clearly defined framework (Matomora, 1995).

Since the International Conference on PHC, held at Alma-Ata in 1979, the call of health for all by the year 2000 through PHC has provided a motivational and unifying concept in international health development (WHO, 1995a). Murray (1990) clarified that after the introduction of the primary health care concept, a variety of vertical programs were launched e.g. Extended Program of Immunization (1977); Selective Primary Health Care (1979); Child Survival and Development Revolution (1982); Safe Motherhood Initiative (1986); and Better Health through Family Planning (1987).

Given that the vertical nature of these programs undermined the holistic idea of the PHC concept, they were heavily criticized. They were considered as movements, of which "each has characteristics of bordering on ideology beyond the simplicity of a program or activity" (Chen, 1988).

Currently the emphasis of health systems development aims at the district level as an intermediate level between the central national structures and the community based structures of the pure PHC approach (WHO, 1987a).

The term "district" denotes a clearly defined administrative unit of local government, which commonly has a population of between 50,000 and 500,000. Its small enough to allow for clear diagnosis of the problems and needs of its 
population, but large enough for sustained mobilization and management of the human, financial, technical, educational and other resources needed to meet local priorities (WHO, 1990).

The following definition of the district health system was adopted by the WHO Global Program Committee in 1986: "A district health system based on primary health care is a more or less self-contained segment of the national health system. It comprises first and foremost a well-defined population, living within a clearly delineated administrative and geographic area, whether urban or rural. It includes all institutions and individuals providing health care in the district, whether governmental, private or traditional. Therefore, it consists of a large variety of interrelated elements that contribute to health in homes, schools, work places and communities, through the health and other sectors" (WHO, 1992).

The district health system is not a new idea: decentralization of control has long been an important political and organizational strategy. Implementing a district health approach based on PHC should take into account the following key strategies: community participation; intersectoral collaboration; affordable technology; equity and social justice; accessibility; emphasis on promotion and prevention; decentralization; and integration of health programs (WHO, 1998). Owino et al (2000) added that effective decentralization empowers the lower level tiers in health planning and management by transferring the responsibilities for planning, management, resource generation and allocation from the Central government.

Tjam (1994) showed that DHS includes all the relevant health care agencies in the area, whether governmental or independent, professional or traditional, which cooperate to create a district system and work together within it. It consists of a large variety of interrelated elements that contribute to community health. It includes self-care and all health care workers and facilities, whether governmental or nongovernmental. It needs to be managed as a single entity, normally under a single fulltime manager who has public health as well as curative responsibilities, in order to draw together all these elements and institutions into a fully comprehensive health activities.

A WHO consultation group (2001) identified the following steps for implementing a healthy district program: establishment of coordinating committee and task force for the various elemental settings programs; extension of existing situation analysis to include the role of all the participating agencies; identification and prioritization of needs; development of a plan of action; mobilization of resources; dissemination and awareness campaigns; training; development of Management Information System (MIS) for surveillance and attaining sustainability; participatory monitoring, reporting and evaluation; document and encourage dissemination of success stories on healthy settings, and replanning (WHO, 2001).

The Department of National Health in South Africa (1995) recommended the following principles for DHS development and implementation: It must overcome fragmentation and accountable to communities; it must be efficient and provide comprehensive primary care services; control must move from the national and provincial levels to the district level; its boundaries should be the same as political and administrative boundaries; and it must promote equity among communities (PHILA, 1998).

Barron (2000) pointed out that there are no definitive guidelines on the scope and depth of primary level services to be rendered by the district health services. The amount of resources available is likely to be the single most important factor in defining what services and how much of each service are delivered.

McCoy and Engelbrecht (1999) clarified that the district health system is the "means" to achieve the "end" of an equitable, efficient and effective health system based on the principles of PHC approach. The underlying essence of the DHS is the organization of health care according to geographic sub-divisions of a country, which are managed through a decentralized management structure. Pailman et al (2000) showed that the 
implementation of the internationally accepted DHS, for the delivery of integrated PHC to all communities, is one of the strategic health objectives. It provides the health sector with a management framework that can deliver health care in a cost-effective and integrated manner. Wahser (1995) pointed out that the integrative paradigm of the district approach creates a compact but complex health system, in which the many historically evolved and the still upcoming entities have to be combined. Meeting the expectations of the communities, the national level, the various vertical programs and the very diversified private sector therefore imposes a great challenge on the management capabilities of the district health team, which is normally constrained by a chronically bad and still worsening economic background.

The health policy in Egypt is in line with the global health policy that aims at achieving health for all by the year 2000 . It calls for the production of primary health care services, satisfying the citizens' needs for drugs and family planning aids at suitable prices, and expansion of health insurance coverage (WHO, 1987b). The basic goals of the Egyptian health care system are: (a) improving population health status and social well-being; (b) ensuring equity and access to care; (c) ensuring microeconomic and macroeconomic efficiency in the use of resources; (d) enhancing clinical effectiveness; (e) improving quality of care and consumer satisfaction; and (f) assuring the system's long-run financial sustainability (MOH, 1998).

Today, most Egyptians have reasonable access to free PHC provided by a government team of health personnel. The system operates through a vast network of more than 2209 rural and 238 urban health units, 161 integrated hospitals, 337 women health centres, 164 maternal and child health centres, 354 health offices, 214 district general hospitals, 196 specialized hospitals, and 13 teaching hospitals and institutes. These are evenly distributed throughout the country. However, the government's success in bringing modern primary health care within reach of most communities has not been matched by a similar success in increasing cultural acceptability (El-Henawy, 2000).

The current five-year development plan stresses economic self-sufficiency, raising productivity and mobilizing local resources. Concurrently, the plan seeks to maintain existing physical and social infrastructure and to improve its performance by doing more with the same resources and/or reducing costs (WHO, 1996).

The district health level, in order to function effectively, must have an efficient and effective referral system. The functional components of the referral system (community, physical infrastructure, health care providers, communication, management information system, resources and finance, and administration and organization) should be analyzed in the context of community involvement, technology, research and equity. The experience of some countries in referral support to PHC was reviewed in relation to regulations, technical guidelines, training, and research. It was found that some countries e.g. Egypt, promulgated policies and/or legislation regarding referral support to $\mathrm{PHC}$ (WHO, 1995b).

Egyptian health system as a whole is characterized by high expenditure and poor outcomes, suggesting that improved health status could be achieved at existing levels of expenditure. In addition, there are major inequities among the population in both access to and financing of care. Unfortunately, the quality of PHC care services has been cited as a problem in most reviews. In effect, poor quality of services led to lack of confidence and underutilization, resulting in rapid turnover of physicians, which, in addition to lack of resources and low treatment standards, further reduced quality (Harmeling, 1999).

\section{Study Objectives: -}

\section{General Objective:}

The study aimed to improve the qualitative and quantitative aspects of primary health care services within the context of the district health system approach in Egypt. 


\section{Specific Objectives:}

In order to achieve the abovementioned objective, the study assessed the functional and administrative situation of health districts, district hospitals and primary health care delivery units to determine their managerial, technical and resources needs for district health system development and implementation.

\section{Material And Methods: -}

Research Setting: The study was conducted in 9 health districts, 35 district hospitals and 201 primary health care facilities chosen randomly from the following governorates of Egypt: El-Giza, Bani-Suaf, El-Garbia, El-Ismailia, ElDakahlia, El-Qalubia and Matrouh .

Research Design: A cross-sectional research design (CSRD) was chosen to investigate the current research problem. A pretest study was carried out during the first two months to help in the finalization of the research instruments and forms as well as the finalization of the study design. It was guided by the following tasks:

1. Testing the forms design, content and language at the study sites.

2. Measuring the time and resources needed for the field -work.

3. Determining the categories and codes for open-ended questions.

4. Training of field supervisors and data collectors.

5. Examining the validity and reliability of the study forms.

Sample Design: The multi-stage random sampling technique was drawn as following:

A. First Stage (Selection of Governorates): The stratified random sampling technique (geographical stratification) has been used to select eight governorates from the twenty-six goverorates of Egypt. This technique yielded the following governorate: Greater Cairo (ElGiza and El-Qalubia) Lower Egypt (ElGarbia and El-Dakahlia), Upper Egypt (Bani-Suef), Suez Cannal Region
(Ismailia) and Frontier Areas

(Matrouh).

B. Second Stage (Selection of Health Districts): By the simple random sampling technique, 9 health districts have been chosen. The following criteria have been considered during the construction of the sampling frame:

The chosen district should not have any major health developmental project.

Existing of many administrative defects. Considering the recommended districts by the Health Sector Reform Project.

C. Third Stage (Selection of district hospitals and PHC units): Depending on the relative importance of the various district hospitals and PHC services delivery modes to the policy and decision makers of the Ministry of Health and Population, 35 district hospitals and 201 PHC units have been selected for investigation.

Also, $50 \mathrm{MOH}$ administrators have been selected from the central authority, health affairs directorates and health districts for the clarity of DHS concept and the willingness towards its implementation in Egypt (third self-administrated questionnaire).

Study Variables: The study variables were classified into structure, process and outcome elements of the study health care system as follow:

1. Structure elements:

Manpower and material.

2. Process elements: Management, technical and financial.

3. Outcome elements.

\section{Data Collection and Management:}

Study Forms: Three different selfadministered questionnaires were used to cover the above-mentioned variables in details as following:

A. The first assessment tool (Health

District Management Level)

developed by the Urban Health

Department (MOHP) and WHO (regional office for the eastern 
Mediterranean region) covered the following selective essential elements:

1. Buildings (ownership, physical accessibility, condition, sanitation, utilities and maintenance services)

2. Transportation vehicle(s).

3. Management issues (problems solving, job descriptions, performance assessment indicators, regular supervision, reporting, selected organizational aspects, coordination and integration activities, quality assurance staffing aspects, management information system and selective information needed for planning).

4. Status of intersectoral collaboration and community participation.

A simple scoring system was developed to judge on each variable through reasonable number of criteria and the final assessment has been presented as shown in the results.

B. The second assessment tool (district hospitals and PHC Units) covered the following variables:

1. Facility renovation.

2. Manpower training needs .

3. Essential equipment list.

4. Essential drugs list.

C. The third self-administered questionnaire (MOHP Administrators and directors of PHC units): It covered 5 different questions about the DHS concept and one question regarding the willingness for DHS implementation.

N.B. After the preliminary data collection and analysis, the researchers organized a workshop in collaboration with the urban health department (MOHP) and presented the preliminary results for open discussion. Thereafter, the results of this workshop together with the final research findings have been utilized in the development of the needed elements for DHS development and implementation in Egypt.

Quality Control: The accuracy of the collected data was ensured through the following measures: The span of supervision was appropriately determined; daily revision of all forms was made by the research members to ensure good quality for the collected data; a regular bi-weekly meeting has been held for the research team (including the data collectors) to identify any constraints that may affect the quality of data and an appropriate actions were taken; the work of data collectors has been subjected to repeated checking to assure accuracy, uniformity and comparability.

Data Processing: The data processing phase of this research started as early as possible to deal with the collected data with great accuracy. We can classify our activities into:

i. Data processing planning stage: Specification what is the research output to be with great precision, determining the best way to produce this output, and allocation of the required resources to achieve this processing speedily and accurately.

ii. Data preparation phase: This phase included editing and coding; initial examination of a sample of the data, and data entry.

Statistical Analysis: The collected data were statistically managed :

Descriptive statistics: The mean and median were used as measures of central tendency. The standard deviation was used as measure of dispersion.

\section{Results And Discussion: -}

Table (1) demonstrated the distribution of the total population served by the studied health districts. The overall mean of population served by the health districts was $373,803 \pm 460,679$. The lowest $(80,000)$ and highest $(832,638 \pm 583486)$ means were observed in Frontier and Lower Egypt districts respectively. Also, It is noticed from the primary data that two health districts (El-Senbalaween and Meet Ghamr) are serving more than 500,000 people. These findings need special considerations form the policy makers as the recommended district population by WHO should be between 50,000 and 
500,000 (WHO, 1990). Also, the well geographical demarcation is not clear especially in Greater Cairo and Lower Egypt governorates. Therefore, we may argue that the proposed DHS by the WHO will not be suitable for a great numbers of the current health districts in Egypt based on the population size and geographical characteristics of many districts.

Table (2) showed the physical aspects of the studied 9 health districts. Its obvious from this table that the studied health districts do not have any major problem regarding the ownership of buildings; refuse and sewage disposals; general cleanliness; and utility supply (water and electricity). While, one district $(11.11 \%)$ in Lower Egypt has an inappropriate physical accessibility and another health district $(11.11 \%)$ in Upper Egypt has a problem with the telephone communication. Meanwhile, only 2 health districts (22.22\%), from Lower Egypt and Suez Canal Region, were included into the current $\mathrm{MOH}$ development plan. Concerning the health districts' architecture and maintenance services, they were good in only $33.33 \%$ and $44.45 \%$ of the studied health districts respectively. Also, 9 health districts $(66.67 \%)$ have un-suitable rooms and 5 health districts $(55.56 \%)$ do have transportation vehicles. We may comment on these findings by addressing the importance of the different structural elements, which are essential requirements for any health function to be performed in good quality, also, It seems to us that a little investment is needed to correct such defects.

Table (3) clarified some important administrative and technical aspects of the studied health districts at the management level. It is very clear that the important issues of problem solving team, standard reference books, and manpower distribution indicators were completely absent in the studied districts. While, the regular reporting to higher authorities was adequately performed by all the studied health districts. But, the majority of health districts $(88.89 \%)$ do have the written job descriptions, regular supervision, organiza-tion of units based on needs, regular food control reports, purchasing of equipment based on needs and quality assurance activities. The process of coordination among health providers and health units was adequate in $22.22 \%$ only of the studied health districts. Performance assessment indicators were present in $33.33 \%$ of the studied districts, while organizational charts were present in $66.67 \%$ of them. Such findings indicate a sever defect in the management and technical aspects of the studied health districts.

Table (4) addressed some important aspects of the Management Information System (MIS), Intersectoral Collaboration and Community Participation of the studied health districts at the management level. It is observed that the sufficient registration of vital data and calculation of vital statistics were $22.22 \%$ and $11.11 \%$ of the studied health districts respectively. While, $88.89 \%$ of the studied districts formulated district's map and $44.44 \%$ of them have determination the served population as an important step for the Geographical Information System (GIS) development. The management of MIS equipment in terms of surplus and shortage has been done in $33.33 \%$ and $77.78 \%$ of the studied districts respectively. Although an intersectoral collaboration council is present, with the local government, in all districts but the private sector show collaboration with only $33.33 \%$ of them. Meanwhile, it's clear that the district health council and district NGOs are present in $22.22 \%$ and $55.56 \%$ of the studied districts only. Also, important community participation activities have been detected in terms of provision of material $(66.67 \%)$ and services $(33.33 \%)$ among the studied health districts.

Table (5) showed the clarity of DHS concept and willingness of the studied $\mathrm{MOH}$ administrators and units' directors towards its implementation. It's clear that the concept is not very clear to most of the studied subjects $(95.10 \%)$, but a better value $(29.37 \%)$ was given towards DHS implementation. These indicate important knowledge gaps that deserve a special consideration from $\mathrm{MOH}$ administrators. Table (6) clarified that all the studied units are in need for training on DHS and 
renovation of $66.17 \%$ of them is an important issue. The chronic problem of sever shortage in essential drugs and equipment are still very obvious.

Based on the previous situational analysis results and $\mathrm{MOH}$ workshop, 33 major DHS developmental needs have been detected (Table, 7). As a starting point, a written generic district health system that suites the Egyptian health care system should be developed, thereafter, it can be adapted for each district as required. Such a generic system should cover the following aspects: mission, goals, objectives, standards, functions, policies and procedures, staffing and organization, interdepartmental relationships, forms and logs, etc..

At the same time, training of midlevel managers should be started immediately to prepare the ground and to develop a favorable attitude towards the new concept of district management system. The major training areas should cover the following: Problem Solving \& Team Building, Management Capabilities Enhancement, Job Descriptions, Intersectoral Collaboration, Community Participation, Total Quality Management, Decentralization in Health Services, Integration of Health Programs, Supervisory Skills, Assessing Community Health Needs, Human Resource Development, Health Management Development, Health Economy. Also, other system supporting activities should be started e.g. research, guidelines, material supply, etc..

Finally, it seems to us that it is very difficult to start the system developmental process in all of the studied districts, although it is very needed. But, we may select 2 districts (as recommended by the workshop participants) to be subjected for the process of system development and institution (Pilot Districts), and try to do the best we can afford for the studied and the other districts of Egypt as shown in Table (7). Also, the Health Sector Reform Project of the Ministry of Health and Population can be very useful in supplying a significant portion of the needed resources, in addition to the already allocated budget from the World Health Organization.

\section{Conclusions And Recommendations:}

\section{Conclusions :}

Based on the results and their discussion, the researchers conclude that the concept of district health system based on primary health care as proposed by the WHO is not very clear for the majority of the Egyptian directors. A very well infrastructure is present allover Egypt that will help in the process of system development and institution to a great extent if properly planned and organized.

The currently available operational costs for system initiation, development and implementation are not enough to a very great degree. Therefore, reallocation of existing resources from the other related sectors of the Ministry of Health and Population is an urgent need to support the establishment of the district health system approach in Egypt.

\section{Recommendations :}

Given the current situation and the very limited material resources, we may recommend the following issues as a starting point for district health system development and implementation in Egypt:

i. Establishment of Task Force Group (Central Level): To help in the initiation of the process of system development and implementation. It may compose of MOHP administrators and researchers from the Egyptian universities.

ii. Formulation of a Technical Group: To provide technical support for system development and implementation. Such a group may be composed of general directors of PHC departments (MOHP), public health and community medicine consultant(s), and WHO consultants.

iii. Working Group Development (Directorate and District Levels): To develop the required action plan. 
iv. Finance and Administration Group Formulation: For the needed financial and administrative transactions.

iv. Conduction of Orientation Workshop(s): To clarify the concept of district health system approach and to get the required administrative and political supports.

v. Development and selection of suitable monitoring and evaluation indicators: A minimum set of indicators should be developed and routinely measured. They should cover the following programmatic aspects: relevance, effectiveness, efficiency, progress, outcome (outputs, effects, and impact), quality, and costeffectiveness.

\section{Acknowledgement:}

For partial financial support, the authors are very grateful to Dr Zohair Halag and the Eastern Mediterranean Regional Office (EMRO) of World Health Organization.

Table (1): Total served population by the studied health districts

\begin{tabular}{|c|c|c|c|c|}
\hline \multirow[b]{2}{*}{ GOVERNORATE/DISTRICT } & \multirow[b]{2}{*}{$\begin{array}{l}\text { GEOGRAPHICA } \\
\text { L LOCATION }\end{array}$} & \multicolumn{3}{|c|}{ POPULATION } \\
\hline & & TOTAL & $\mathrm{X} \pm \mathrm{SD}$ & MEDIAN \\
\hline $\begin{array}{l}\text { EL-GIZA: } \\
\text { El-Suaf }\end{array}$ & \multirow{2}{*}{ Greater Cairo } & 355082 & \multirow[b]{2}{*}{$203041 \pm 215018$} & \multirow[b]{2}{*}{203041} \\
\hline $\begin{array}{l}\text { EL-QALUBIA: } \\
\text { Sheben El-Kanatr }\end{array}$ & & 51000 & & \\
\hline $\begin{array}{l}\text { EI-DAKAHLIA: } \\
\text { Meet Ghamr } \\
\text { El-Sanbalaween }\end{array}$ & \multirow[t]{2}{*}{ Lower Egypt } & $\begin{array}{l}579125 \\
1500000\end{array}$ & \multirow[t]{2}{*}{$832638 \pm 583486$} & \multirow[t]{2}{*}{579125} \\
\hline $\begin{array}{l}\text { EL-GARBIA: } \\
\text { Zefta }\end{array}$ & & 418788 & & \\
\hline $\begin{array}{l}\text { BANI-SUEF: } \\
\text { Ahnasia }\end{array}$ & Upper Egypt & 212935 & 212935 & 212935 \\
\hline $\begin{array}{l}\text { ISMAILIA: } \\
\text { Fayed } \\
\text { El-Kasasyn }\end{array}$ & $\begin{array}{l}\text { Suez Canal } \\
\text { Region }\end{array}$ & $\begin{array}{l}74300 \\
93000\end{array}$ & $83650 \pm 13223$ & 83650 \\
\hline $\begin{array}{l}\text { MATROUH: } \\
\text { El-Hamam }\end{array}$ & Frontier Areas & 80000 & 80000 & 80000 \\
\hline ALL DISTRICTS & & & $373803 \pm 460679$ & 212935 \\
\hline
\end{tabular}


Table (2): Physical Aspects Of The Studied Health Districts At The Management Level

\begin{tabular}{|c|c|c|c|c|c|c|c|c|c|c|c|c|}
\hline \multirow{3}{*}{ ASPECT } & \multicolumn{12}{|c|}{ STUDIED DISTRICTS } \\
\hline & \multicolumn{2}{|c|}{$\begin{array}{l}\text { Upper Egypt } \\
\qquad(\mathrm{N}=1)\end{array}$} & \multicolumn{2}{|c|}{$\begin{array}{c}\text { Lower Egypt } \\
(\mathbf{N}=3)\end{array}$} & \multicolumn{2}{|c|}{$\begin{array}{l}\text { Greater Cairo } \\
(\mathrm{N}=2)\end{array}$} & \multicolumn{2}{|c|}{$\begin{array}{c}\text { Suez Canal } \\
\text { Region } \\
(\mathrm{N}=2)\end{array}$} & \multicolumn{2}{|c|}{$\begin{array}{c}\text { Frontier } \\
\text { Areas } \\
(\mathbf{N}=1)\end{array}$} & \multicolumn{2}{|c|}{$\begin{array}{l}\text { Total } \\
(\mathrm{N}=9)\end{array}$} \\
\hline & No. & $\%$ & No. & $\%$ & No. & $\%$ & No. & $\%$ & $\begin{array}{l}\mathbf{N} \\
\mathbf{0 .}\end{array}$ & $\%$ & No. & $\%$ \\
\hline $\begin{array}{l}\text { OWNERSHIP OF } \\
\text { BUILDING: } \\
\text { Governmental } \\
\text { Private Sector } \\
\end{array}$ & $\begin{array}{l}1 \\
- \\
\end{array}$ & $\begin{array}{c}100.00 \\
-\end{array}$ & $\begin{array}{l}3 \\
-\end{array}$ & $\begin{array}{c}100.00 \\
-\end{array}$ & $\begin{array}{l}2 \\
-\end{array}$ & $\begin{array}{c}100.00 \\
-\end{array}$ & $\begin{array}{l}2 \\
-\end{array}$ & $\begin{array}{c}100.00 \\
-\end{array}$ & $\begin{array}{l}1 \\
-\end{array}$ & $\begin{array}{c}100.00 \\
-\end{array}$ & $\begin{array}{l}9 \\
-\end{array}$ & $\begin{array}{c}100.00 \\
-\end{array}$ \\
\hline $\begin{array}{l}\text { PHYSICAL } \\
\text { ACCESSIBILITY: } \\
\text { Appropriate } \\
\text { Inappropriate } \\
\end{array}$ & $\begin{array}{l}1 \\
- \\
\end{array}$ & $\begin{array}{c}100.00 \\
-\end{array}$ & $\begin{array}{l}2 \\
1\end{array}$ & $\begin{array}{l}66.67 \\
33.33 \\
\end{array}$ & $\begin{array}{l}2 \\
-\end{array}$ & $\begin{array}{c}100.00 \\
-\end{array}$ & $\begin{array}{l}2 \\
- \\
\end{array}$ & $\begin{array}{c}100.00 \\
-\end{array}$ & $\begin{array}{l}1 \\
-\end{array}$ & $\begin{array}{c}100.00 \\
-\end{array}$ & $\begin{array}{l}8 \\
1\end{array}$ & $\begin{array}{l}88.89 \\
11.11\end{array}$ \\
\hline $\begin{array}{l}\text { ARCHITECTURE: } \\
\text { Good } \\
\text { Fair } \\
\text { Poor } \\
\text { Very Poor }\end{array}$ & $\begin{array}{l}- \\
1 \\
- \\
-\end{array}$ & $\begin{array}{c}- \\
100.00 \\
- \\
-\end{array}$ & $\begin{array}{l}1 \\
1 \\
1 \\
-\end{array}$ & $\begin{array}{c}33.33 \\
33.33 \\
33.33 \\
-\end{array}$ & $\begin{array}{l}1 \\
1 \\
- \\
-\end{array}$ & $\begin{array}{l}50.00 \\
50.00 \\
- \\
-\end{array}$ & $\begin{array}{l}1 \\
1 \\
- \\
-\end{array}$ & $\begin{array}{l}50.00 \\
50.00 \\
- \\
-\end{array}$ & $\begin{array}{l}- \\
- \\
- \\
1\end{array}$ & $\begin{array}{c}- \\
- \\
- \\
100.00\end{array}$ & $\begin{array}{l}3 \\
4 \\
1 \\
1\end{array}$ & $\begin{array}{l}33.33 \\
44.45 \\
11.11 \\
11.11\end{array}$ \\
\hline $\begin{array}{l}\text { MOH } \\
\text { DEVELOPMENTAL } \\
\text { PLAN: } \\
\quad \text { Included } \\
\quad \text { Not Included }\end{array}$ & $\begin{array}{l}- \\
1\end{array}$ & 100.00 & $\begin{array}{l}1 \\
2\end{array}$ & $\begin{array}{l}33.33 \\
66.67\end{array}$ & - & 100.00 & $\begin{array}{l}1 \\
1\end{array}$ & $\begin{array}{l}50.00 \\
50.00\end{array}$ & $\begin{array}{l}- \\
1\end{array}$ & 100.00 & $\begin{array}{l}2 \\
7\end{array}$ & $\begin{array}{l}22.22 \\
77.78\end{array}$ \\
\hline $\begin{array}{l}\text { SUITABILITY OF } \\
\text { ROOMS: } \\
\text { Suitable } \\
\text { Not Suitable }\end{array}$ & $\begin{array}{l}- \\
1\end{array}$ & $\begin{array}{c}- \\
100.00\end{array}$ & $\begin{array}{l}1 \\
2\end{array}$ & $\begin{array}{l}33.33 \\
66.67\end{array}$ & $\begin{array}{l}1 \\
1\end{array}$ & $\begin{array}{l}50.00 \\
50.00\end{array}$ & $\begin{array}{l}1 \\
1\end{array}$ & $\begin{array}{l}50.00 \\
50.00\end{array}$ & $\begin{array}{l}- \\
1\end{array}$ & 100.00 & $\begin{array}{l}3 \\
6\end{array}$ & $\begin{array}{l}33.33 \\
66.67\end{array}$ \\
\hline $\begin{array}{l}\text { NUMBER OF } \\
\text { ROOMS: }(\mathrm{X} \pm \mathrm{SD}) \\
\end{array}$ & & & 12. & \pm 3.00 & 10. & \pm 2.12 & & \pm 6.36 & & .00 & & \pm 4.28 \\
\hline $\begin{array}{l}\text { REFUSE AND } \\
\text { SEWAGE } \\
\text { DISPOSAL: } \\
\quad \text { Good } \\
\quad \text { Bad } \\
\end{array}$ & $\begin{array}{l}1 \\
-\end{array}$ & $\begin{array}{c}100.00 \\
-\end{array}$ & $\begin{array}{l}3 \\
-\end{array}$ & $\begin{array}{c}100.00 \\
-\end{array}$ & $\begin{array}{l}2 \\
-\end{array}$ & $\begin{array}{c}100.00 \\
-\end{array}$ & $\begin{array}{l}2 \\
- \\
\end{array}$ & $\begin{array}{c}100.00 \\
-\end{array}$ & $\begin{array}{l}1 \\
-\end{array}$ & $\begin{array}{c}100.00 \\
-\end{array}$ & $\begin{array}{l}9 \\
-\end{array}$ & $\begin{array}{c}100.00 \\
-\end{array}$ \\
\hline $\begin{array}{l}\text { CLEANLINESS: } \\
\text { Good } \\
\text { Bad }\end{array}$ & $\begin{array}{l}1 \\
-\end{array}$ & $\begin{array}{c}100.00 \\
-\end{array}$ & $\begin{array}{l}3 \\
-\end{array}$ & $\begin{array}{c}100.00 \\
-\end{array}$ & $\begin{array}{l}2 \\
-\end{array}$ & $\begin{array}{c}100.00 \\
-\end{array}$ & $\begin{array}{l}2 \\
-\end{array}$ & $\begin{array}{c}100.00 \\
-\end{array}$ & $\begin{array}{l}1 \\
-\end{array}$ & $\begin{array}{c}100.00 \\
-\end{array}$ & $\begin{array}{l}9 \\
-\end{array}$ & $\begin{array}{c}100.00 \\
-\end{array}$ \\
\hline $\begin{array}{l}\text { WATER CLOSET : } \\
\text { Good } \\
\text { Bad }\end{array}$ & $\begin{array}{l}1 \\
-\end{array}$ & $\begin{array}{c}100.00 \\
-\end{array}$ & $\begin{array}{l}3 \\
-\end{array}$ & $\begin{array}{c}100.00 \\
-\end{array}$ & $\begin{array}{l}2 \\
-\end{array}$ & $\begin{array}{c}100.00 \\
-\end{array}$ & $\begin{array}{l}2 \\
-\end{array}$ & $\begin{array}{c}100.00 \\
-\end{array}$ & $\begin{array}{l}1 \\
-\end{array}$ & $\begin{array}{c}100.00 \\
-\end{array}$ & $\begin{array}{l}9 \\
-\end{array}$ & $\begin{array}{c}100.00 \\
-\end{array}$ \\
\hline $\begin{array}{l}\text { WATER AND } \\
\text { ELECTRICITY: } \\
\text { Good } \\
\text { Bad }\end{array}$ & $\begin{array}{l}1 \\
-\end{array}$ & $\begin{array}{c}100.00 \\
-\end{array}$ & $\begin{array}{l}3 \\
-\end{array}$ & $\begin{array}{c}100.00 \\
-\end{array}$ & $\begin{array}{l}2 \\
-\end{array}$ & $\begin{array}{c}100.00 \\
-\end{array}$ & $\begin{array}{l}2 \\
-\end{array}$ & $\begin{array}{c}100.00 \\
-\end{array}$ & $\begin{array}{l}1 \\
-\end{array}$ & $\begin{array}{c}100.00 \\
-\end{array}$ & $\begin{array}{l}9 \\
-\end{array}$ & $\begin{array}{c}100.00 \\
-\end{array}$ \\
\hline $\begin{array}{l}\text { TELEPHONE } \\
\text { Present } \\
\text { Absent }\end{array}$ & - & $\begin{array}{c}- \\
100.00\end{array}$ & $\begin{array}{l}3 \\
-\end{array}$ & $\begin{array}{c}100.00 \\
-\end{array}$ & $\begin{array}{l}2 \\
-\end{array}$ & $\begin{array}{c}100.00 \\
-\end{array}$ & $\begin{array}{l}2 \\
-\end{array}$ & $\begin{array}{c}100.00 \\
-\end{array}$ & $\begin{array}{l}1 \\
-\end{array}$ & $\begin{array}{c}100.00 \\
-\end{array}$ & $\begin{array}{l}8 \\
1\end{array}$ & $\begin{array}{l}88.89 \\
11.11\end{array}$ \\
\hline $\begin{array}{l}\text { VEHICLE (S): } \\
\text { Present } \\
\text { Absent }\end{array}$ & $\begin{array}{l}1 \\
-\end{array}$ & $\begin{array}{c}100.00 \\
-\end{array}$ & $\begin{array}{l}2 \\
1\end{array}$ & $\begin{array}{l}66.67 \\
33.33\end{array}$ & $\begin{array}{l}1 \\
1\end{array}$ & $\begin{array}{l}50.00 \\
50.00\end{array}$ & - & $\begin{array}{c}- \\
100.00\end{array}$ & $\begin{array}{l}- \\
1\end{array}$ & $\begin{array}{c}- \\
100.00\end{array}$ & $\begin{array}{l}4 \\
5\end{array}$ & $\begin{array}{l}44.44 \\
55.56\end{array}$ \\
\hline $\begin{array}{l}\text { MAINTENANCE } \\
\text { SERVICES: } \\
\text { Good } \\
\text { Fair } \\
\text { Poor }\end{array}$ & $\begin{array}{l}- \\
- \\
1\end{array}$ & $\begin{array}{c}- \\
- \\
100.00\end{array}$ & $\begin{array}{l}3 \\
- \\
-\end{array}$ & $\begin{array}{c}100.00 \\
- \\
-\end{array}$ & $\begin{array}{l}1 \\
1 \\
-\end{array}$ & $\begin{array}{c}50.00 \\
50.00 \\
-\end{array}$ & $\begin{array}{l}- \\
- \\
2\end{array}$ & $\begin{array}{c}- \\
- \\
100.00\end{array}$ & $\begin{array}{l}- \\
1 \\
-\end{array}$ & $\begin{array}{c}- \\
100.00 \\
-\end{array}$ & $\begin{array}{l}4 \\
2 \\
3\end{array}$ & $\begin{array}{l}44.45 \\
22.22 \\
33.33\end{array}$ \\
\hline
\end{tabular}

N.; Number of Sampled Districts 
Table (3): Administrative And Technical Aspects Of The Studied Health Districts At The Management Level

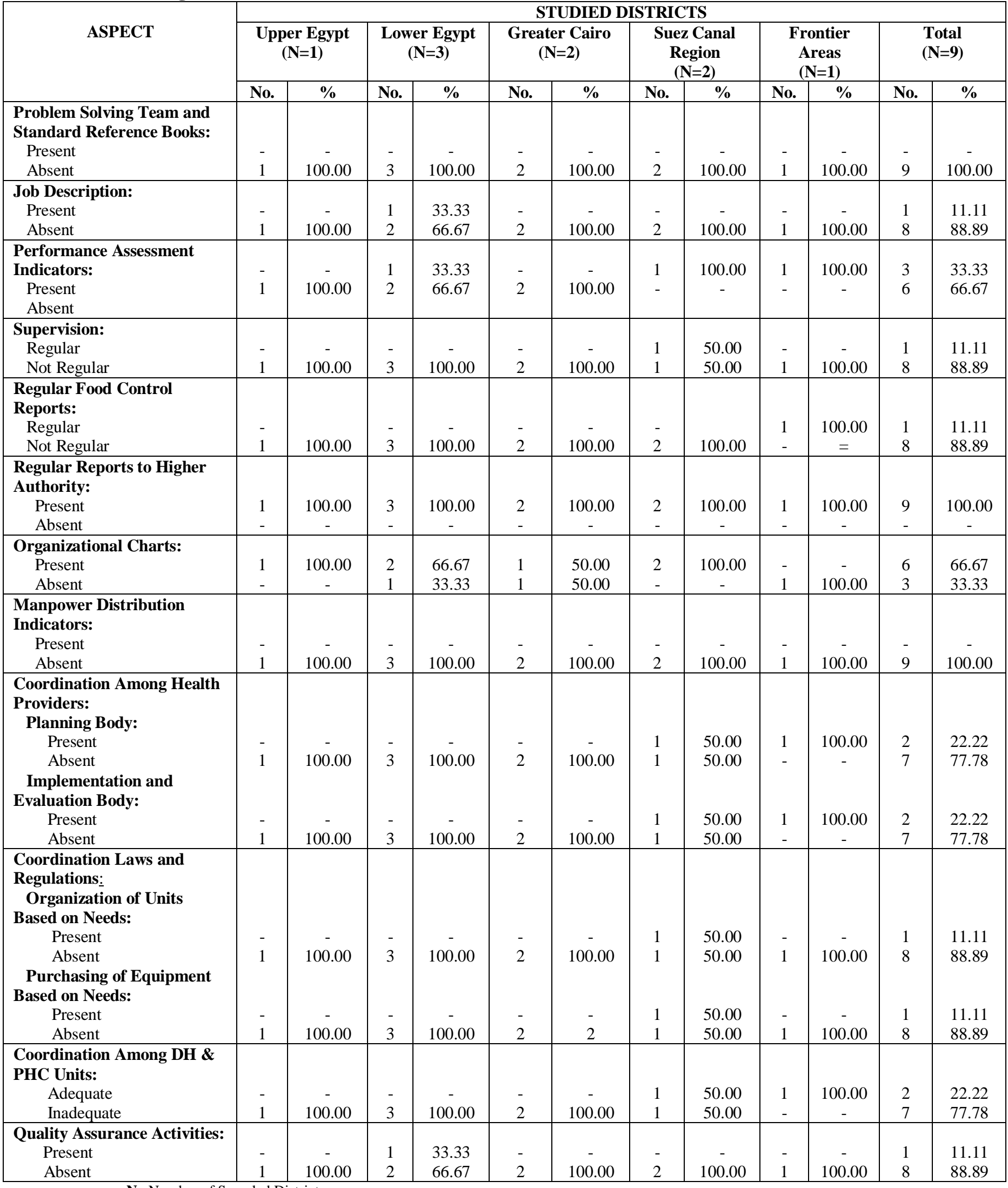


Table (4): Management Information System, Intersectoral Collaboration And Community Participation Of The Studied Health Districts At The Management Level

\begin{tabular}{|c|c|c|c|c|c|c|c|c|c|c|c|c|}
\hline \multirow{3}{*}{ ASPECT } & \multicolumn{12}{|c|}{ STUDIED DISTRICTS } \\
\hline & \multicolumn{2}{|c|}{$\begin{array}{l}\text { Upper } \\
\text { Egypt } \\
(\mathrm{N}=1)\end{array}$} & \multicolumn{2}{|c|}{$\begin{array}{l}\text { Lower Egypt } \\
(\mathbf{N}=\mathbf{3})\end{array}$} & \multicolumn{2}{|c|}{$\begin{array}{l}\text { Greater Cairo } \\
\qquad(\mathbf{N}=\mathbf{2})\end{array}$} & \multicolumn{2}{|c|}{$\begin{array}{l}\text { Suez Canal } \\
\text { Region } \\
(\mathbf{N}=2)\end{array}$} & \multicolumn{2}{|c|}{$\begin{array}{l}\text { Frontier Areas } \\
\qquad(\mathbf{N}=\mathbf{1})\end{array}$} & \multicolumn{2}{|c|}{$\begin{array}{l}\text { Total } \\
(\mathrm{N}=9)\end{array}$} \\
\hline & No. & $\%$ & No. & $\%$ & No. & $\%$ & No. & $\%$ & No. & $\%$ & No. & $\%$ \\
\hline MANAGEMENT INFORMATI & SYST & M: & & & & & & & & & & \\
\hline $\begin{array}{l}\text { Registration of Vital Data } \\
\text { Sufficient } \\
\text { Insufficient } \\
\end{array}$ & $\overline{1}$ & 100.00 & - & 100.00 & $\begin{array}{l}1 \\
1 \\
\end{array}$ & $\begin{array}{l}50.00 \\
50.00 \\
\end{array}$ & $\begin{array}{l}1 \\
1 \\
\end{array}$ & $\begin{array}{l}50.00 \\
50.00 \\
\end{array}$ & $\overline{1}$ & 100.00 & $\begin{array}{l}2 \\
7 \\
\end{array}$ & $\begin{array}{l}22.22 \\
77.78 \\
\end{array}$ \\
\hline $\begin{array}{l}\text { Calculation of Vital Statistics }{ }^{\mathbf{b}} \text { : } \\
\text { Sufficient } \\
\text { Insufficient }\end{array}$ & $\overline{1}$ & $10 \overline{-} .00$ & - & 100.00 & $\overline{2}$ & 100.00 & $\begin{array}{l}1 \\
1 \\
\end{array}$ & $\begin{array}{l}50.00 \\
50.00 \\
\end{array}$ & $\overline{1}$ & 100.00 & $\begin{array}{l}1 \\
8 \\
\end{array}$ & $\begin{array}{l}11.11 \\
88.89 \\
\end{array}$ \\
\hline $\begin{array}{l}\text { Preliminary GIS: - } \\
\text { Formulation of District's Map: } \\
\text { Done } \\
\text { Not Done } \\
\text { Determination of Served } \\
\text { Population: } \\
\text { Done } \\
\text { Not Done } \\
\end{array}$ & $\begin{array}{l}1 \\
- \\
- \\
1\end{array}$ & $\begin{array}{c}100.00 \\
- \\
- \\
100.00\end{array}$ & $\begin{array}{l}2 \\
1 \\
\\
2 \\
1\end{array}$ & $\begin{array}{l}66.67 \\
33.33 \\
\\
66.67 \\
33.33\end{array}$ & $\begin{array}{l}2 \\
- \\
- \\
2\end{array}$ & $\begin{array}{c}100.00 \\
- \\
- \\
100.00\end{array}$ & $\begin{array}{l}2 \\
- \\
1 \\
1\end{array}$ & $\begin{array}{c}100.00 \\
- \\
50.00 \\
50.00\end{array}$ & $\begin{array}{l}1 \\
- \\
1 \\
-\end{array}$ & $\begin{array}{c}100.00 \\
- \\
100.00 \\
-\end{array}$ & $\begin{array}{l}8 \\
1 \\
4 \\
5\end{array}$ & $\begin{array}{l}88.89 \\
11.11 \\
\\
44.44 \\
55.56\end{array}$ \\
\hline $\begin{array}{l}\text { Management of Equipment: - } \\
\text { Determination Surplus in Units: } \\
\text { Done } \\
\text { Not Done } \\
\text { Determination of Shortages in } \\
\text { Units: } \\
\\
\quad \text { Done } \\
\text { Not Done } \\
\end{array}$ & $\begin{array}{l}1 \\
- \\
1 \\
-\end{array}$ & $\begin{array}{c}100.00 \\
- \\
100.00 \\
-\end{array}$ & $\begin{array}{l}- \\
3 \\
2 \\
1\end{array}$ & $\begin{array}{c}- \\
100.00 \\
66.67 \\
33.33\end{array}$ & $\begin{array}{l}1 \\
1 \\
1 \\
1\end{array}$ & $\begin{array}{l}50.00 \\
50.00 \\
\\
50.00 \\
50.00\end{array}$ & $\begin{array}{l}1 \\
1 \\
2 \\
-\end{array}$ & $\begin{array}{c}50.00 \\
50.00 \\
100.00 \\
-\end{array}$ & $\begin{array}{l}- \\
1 \\
1 \\
-\end{array}$ & $\begin{array}{c}- \\
100.00 \\
100.00 \\
-\end{array}$ & $\begin{array}{l}3 \\
6 \\
7 \\
2\end{array}$ & $\begin{array}{l}33.33 \\
66.67 \\
\\
77.78 \\
22.22\end{array}$ \\
\hline $\begin{array}{l}\text { INTERSECTORAL COLLABO } \\
\text { Intersectoral Council: } \\
\text { Present } \\
\text { Absent }\end{array}$ & $\begin{array}{l}1 \\
-\end{array}$ & $\begin{array}{c}100.00 \\
-\end{array}$ & $\begin{array}{l}3 \\
-\end{array}$ & $\begin{array}{c}100.00 \\
-\end{array}$ & $\begin{array}{l}2 \\
-\end{array}$ & $\begin{array}{c}100.00 \\
-\end{array}$ & $\begin{array}{l}2 \\
-\end{array}$ & $\begin{array}{c}100.00 \\
-\end{array}$ & $\begin{array}{l}1 \\
-\end{array}$ & $\begin{array}{c}100.00 \\
-\end{array}$ & $\begin{array}{l}9 \\
-\end{array}$ & $\begin{array}{c}100.00 \\
-\end{array}$ \\
\hline $\begin{array}{l}\text { Private Sector: } \\
\text { Involved } \\
\text { Not Involved } \\
\end{array}$ & $\overline{1}$ & 100.00 & $\begin{array}{l}1 \\
2 \\
\end{array}$ & $\begin{array}{l}33.33 \\
66.67 \\
\end{array}$ & $\begin{array}{l}1 \\
1\end{array}$ & $\begin{array}{l}50.00 \\
50.00 \\
\end{array}$ & $\begin{array}{l}1 \\
1\end{array}$ & $\begin{array}{l}50.00 \\
50.00 \\
\end{array}$ & $\overline{1}$ & 100.00 & $\begin{array}{l}3 \\
6 \\
\end{array}$ & $\begin{array}{l}33.33 \\
66.67 \\
\end{array}$ \\
\hline COMMUNITY PARTICIPATIO & & & & & & & & & & & & \\
\hline $\begin{array}{l}\text { District Health Council: } \\
\text { Present } \\
\text { Absent } \\
\end{array}$ & $\overline{1}$ & $\begin{array}{c}- \\
100.00\end{array}$ & $\begin{array}{l}1 \\
2 \\
\end{array}$ & $\begin{array}{l}33.33 \\
66.67 \\
\end{array}$ & $\overline{2}$ & 100.00 & - & $10 \overline{-} .00$ & $\begin{array}{l}1 \\
- \\
\end{array}$ & $\begin{array}{c}100.00 \\
-\end{array}$ & $\begin{array}{l}2 \\
7 \\
\end{array}$ & $\begin{array}{l}22.22 \\
77.78 \\
\end{array}$ \\
\hline $\begin{array}{l}\text { Presence of District NGOs: } \\
\text { Present } \\
\text { Absent } \\
\end{array}$ & $\overline{1}$ & $\begin{array}{c}- \\
100.00 \\
\end{array}$ & $\begin{array}{l}1 \\
2 \\
\end{array}$ & $\begin{array}{l}33.33 \\
66.67 \\
\end{array}$ & $\begin{array}{l}1 \\
1 \\
\end{array}$ & $\begin{array}{l}50.00 \\
50.00 \\
\end{array}$ & $\begin{array}{l}2 \\
- \\
\end{array}$ & $\begin{array}{c}100.00 \\
-\end{array}$ & $\begin{array}{l}1 \\
-\end{array}$ & $\begin{array}{c}100.00 \\
-\end{array}$ & $\begin{array}{l}5 \\
4 \\
\end{array}$ & $\begin{array}{r}55.56 \\
44.44 \\
\end{array}$ \\
\hline $\begin{array}{l}\text { Population Participation: } \\
\text { Material and/or money } \\
\text { Donation: } \\
\text { Present } \\
\text { Absent } \\
\text { Provision of Services: } \\
\text { Present } \\
\text { Absent } \\
\end{array}$ & $\overline{1}$ & $\begin{array}{c}- \\
100.00 \\
- \\
100.00\end{array}$ & $\begin{array}{l}3 \\
-\end{array}$ & $\begin{array}{c}100.00 \\
- \\
100.00 \\
-\end{array}$ & $\begin{array}{l}1 \\
1 \\
- \\
2\end{array}$ & $\begin{array}{c}50.00 \\
50.00 \\
- \\
100.00\end{array}$ & $\begin{array}{l}2 \\
- \\
2 \\
-\end{array}$ & $\begin{array}{c}100.00 \\
- \\
100.00 \\
-\end{array}$ & $\overline{-}$ & $\begin{array}{c}- \\
100.00 \\
- \\
100.00\end{array}$ & $\begin{array}{l}6 \\
3\end{array}$ & $\begin{array}{l}66.67 \\
33.33 \\
\\
33.33 \\
66.67\end{array}$ \\
\hline
\end{tabular}

N.; Number of Sampled Districts

a: Minimum Required Data: served population, no. of houses, age and sex distribution, family size, educational level, and sanitary conditions of houses.

b; Minimum Required Rates: CBR, CDR, TFR, IMR, Under 5 MR, MMR, Cause of Death, Incidence and Prevalence of Communicable and Non-Communicable Diseases. 
Table (5): Clarity Of District Health System Concept And Willingess Towards Its Implementation By The Studied Moh Administrators And Units' Directors

\begin{tabular}{|c|c|c|c|c|c|c|c|c|}
\hline \multirow{3}{*}{ ASPECT } & \multicolumn{8}{|c|}{ TARGET POPULATION } \\
\hline & \multicolumn{2}{|c|}{$\begin{array}{c}\text { MOH } \\
\text { Administrators } \\
(\mathbf{N}=\mathbf{5 0})\end{array}$} & \multicolumn{2}{|c|}{$\begin{array}{l}\text { District Hospitals } \\
\text { Directors } \\
(\mathbf{N}=35)\end{array}$} & \multicolumn{2}{|c|}{$\begin{array}{l}\text { PHC Units' Directors } \\
(\mathrm{N}=\mathbf{2 0 1})\end{array}$} & \multicolumn{2}{|c|}{$\begin{array}{c}\text { Total } \\
(\mathbf{N}=\mathbf{2 8 6})\end{array}$} \\
\hline & No. & $\%$ & No. & $\%$ & No. & $\%$ & No. & $\%$ \\
\hline $\begin{array}{l}\text { DHS Concept Clarity: } \\
\text { Very Clear } \\
\text { Clear } \\
\text { Not Clear }\end{array}$ & $\begin{array}{c}9 \\
15 \\
26\end{array}$ & $\begin{array}{l}18.00 \\
30.00 \\
52.00\end{array}$ & $\begin{array}{c}2 \\
8 \\
25\end{array}$ & $\begin{array}{c}5.71 \\
22.86 \\
71.43\end{array}$ & $\begin{array}{c}3 \\
27 \\
171\end{array}$ & $\begin{array}{c}1.50 \\
13.43 \\
85.07\end{array}$ & $\begin{array}{c}14 \\
50 \\
222\end{array}$ & $\begin{array}{r}4.90 \\
17.48 \\
77.62\end{array}$ \\
\hline $\begin{array}{l}\text { DHS Implementation } \\
\text { Willingness: } \\
\text { Willing } \\
\text { Not Willing }\end{array}$ & $\begin{array}{l}32 \\
18\end{array}$ & $\begin{array}{l}64.00 \\
36.00\end{array}$ & $\begin{array}{l}11 \\
24\end{array}$ & $\begin{array}{l}31.43 \\
68.57\end{array}$ & $\begin{array}{c}41 \\
160\end{array}$ & $\begin{array}{l}20.40 \\
79.60\end{array}$ & $\begin{array}{c}84 \\
202\end{array}$ & $\begin{array}{l}29.37 \\
70.63\end{array}$ \\
\hline
\end{tabular}

Table (6): Health Units' Needs For District Health System Development And Implementation

\begin{tabular}{|c|c|c|c|c|}
\hline \multirow{3}{*}{ ASPECT } & \multicolumn{4}{|c|}{ STUDIED HEALTH UNITS } \\
\hline & \multicolumn{2}{|c|}{$\begin{array}{c}\text { District Hospitals } \\
(\mathrm{N}=35)\end{array}$} & \multicolumn{2}{|c|}{$\begin{array}{c}\text { PHC Units } \\
(\mathrm{N}=201)\end{array}$} \\
\hline & No. & $\%$ & No. & $\%$ \\
\hline $\begin{array}{l}\text { Facility Renovation: } \\
\text { Needed } \\
\text { Not Needed }\end{array}$ & $\begin{array}{c}32 \\
3\end{array}$ & $\begin{array}{c}91.43 \\
8.57\end{array}$ & $\begin{array}{c}133 \\
68\end{array}$ & $\begin{array}{l}66.17 \\
33.83\end{array}$ \\
\hline $\begin{array}{l}\text { Manpower DHS } \\
\text { Training: } \\
\text { Needed } \\
\text { Not Needed } \\
\end{array}$ & $\begin{array}{c}35 \\
- \\
\end{array}$ & $\begin{array}{c}100.00 \\
-\end{array}$ & $\begin{array}{c}201 \\
-\end{array}$ & $\begin{array}{c}100.00 \\
-\end{array}$ \\
\hline 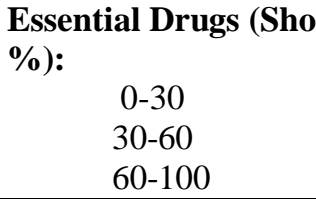 & $\begin{array}{c}- \\
4 \\
31\end{array}$ & $\begin{array}{c}- \\
11.43 \\
88.57\end{array}$ & $\begin{array}{c}- \\
- \\
201\end{array}$ & $\begin{array}{c}- \\
- \\
100.00\end{array}$ \\
\hline $\begin{array}{c}\text { Essential Equipment } \\
\text { (Shortage \%): } \\
0-30 \\
30-60 \\
60-100 \\
\end{array}$ & $\begin{array}{c}- \\
7 \\
28\end{array}$ & $\begin{array}{l}- \\
20.00 \\
80.00\end{array}$ & $\begin{array}{c}- \\
7 \\
194 \\
\end{array}$ & $\begin{array}{c}- \\
3.48 \\
96.52 \\
\end{array}$ \\
\hline
\end{tabular}


Table (7): District Health System Developmental Needs In Egypt

\begin{tabular}{|c|c|c|c|c|}
\hline \multirow{2}{*}{ Developmental Area } & \multicolumn{4}{|c|}{ Health System Needs } \\
\hline & Development & Training Courses & Supply & Others \\
\hline Generic District Health System & Written System & 2 Pilot Districts & 10 Districts & - \\
\hline Reference Books & - & 2 Pilot District & All Districts & Presentation (10 Districts) \\
\hline Problem Solving \& Team Building & Training Manual & 10 Districts & 10 Districts & - \\
\hline $\begin{array}{lr}\text { Management } & \begin{array}{r}\text { Capabilities } \\
\text { Enhancement }\end{array}\end{array}$ & Training Manual & 10 Districts & 10 Districts & Assessment (Research) \\
\hline DHS Developmental Plan & Plan & - & Directorates & Coordination \\
\hline Job Descriptions & Manual & 2 Pilot District & All Districts & - \\
\hline Performance Assessment Indicators & Establishment & 10 Districts & All Districts & - \\
\hline Productivity Improvement Program & Program & 2 Pilot District & All Districts & - \\
\hline Intersectoral Collaboration & Guidelines & 10 Districts & 10 Districts & - \\
\hline Community Participation & Guidelines & 10 Districts & 10 Districts & - \\
\hline Community Health Needs & Training Manual & 10 Districts & 10 Districts & Research \\
\hline Integration of Health Programs & Guidelines & 10 Districts & All Districts & - \\
\hline $\begin{array}{rrrr}\text { Surveillance of } & \begin{array}{r}\text { Morbidity } \\
\text { Mortality }\end{array} \\
\end{array}$ & Training Manual & 2 Pilot Districts & 10 Districts & - \\
\hline Total Quality Management & System & 2 Pilot Districts & 10 Districts & Research \\
\hline Management Information System & System & 2 Pilot Districts & 10 Districts & - \\
\hline Medical and Health Records & System & 2 Pilot Districts & 10 Districts & - \\
\hline Decentralization in Health Services & Guidelines & 10 Districts & All Districts & - \\
\hline Assessing Information Needs & Training Manual & 10 Districts & All Districts & Research (2 Pilot District) \\
\hline Health Economy & Guidelines & 10 Districts & 10 Districts & - \\
\hline Rapid Assessment Surveys in Districts & Guidelines & 2 Pilot Districts & 10 Districts & - \\
\hline Supervisory Skills & Training Manual & 2 Pilot Districts & 10 Districts & - \\
\hline Health Care Needs and Demand & Guidelines & 2 Pilot Districts & 10 Districts & - \\
\hline Human Resource Development & Training Manual & 2 Pilot Districts & 10 Districts & - \\
\hline Health Management Development & Training Manual & 2 Pilot Districts & 10 Districts & - \\
\hline Utilization of Computer & - & 10 Districts & $\begin{array}{c}2 \text { Pilot } \\
\text { Districts }\end{array}$ & - \\
\hline Monitoring and Evaluating Programs & Guidelines & 10 Districts & 10 Districts & - \\
\hline $\begin{array}{llr}\text { Cost-Effectiveness } & \begin{array}{c}\text { of } \\
\text { Approaches }\end{array} \\
\end{array}$ & - & - & - & Research \\
\hline Geographical Adjustment & - & - & - & Research \\
\hline Capacity Utilization & - & - & - & Research \\
\hline Essential Drugs & - & - & $\begin{array}{c}\text { 2 Pilot } \\
\text { Districts }\end{array}$ & - \\
\hline Essential Equipment & - & - & $\begin{array}{l}2 \text { Pilot } \\
\text { Districts }\end{array}$ & - \\
\hline Renovation & - & - & $\begin{array}{l}2 \text { Pilot } \\
\text { Districts }\end{array}$ & - \\
\hline Technical Assistance & - & - & - & Egyptian Universities \\
\hline
\end{tabular}




\section{References:}

1. Barron, P. (2000): Editorial, The District Health System : Progress to Date, Up-Date. Issue No. 51.

2. Chen, L. (1988): Ten Years After Alma Ata: Balancing Different Primary Health Care Strategies. Tropical and Geographical Medicine . 40: S22-S29.

3. El-Henawy, A. (2000): Current Situation, Progress and Prospects of Health for All in Egypt. Eastern Mediterranean Health Journal, Vol. 6, Issue 4; 816-821.

4. Harmeling, S. (1999): Health Reform in Egypt Case study for Module 3: "Reproductive Health and Health Sector Reform", Harvard University, Core Course on "Population, Reproductive Health and Health Sector Reform" ,World Bank Institute, p.3.

5. Matomora, K. (1995): The District Health Systems Approach. Contact; 143: 7-14.

6. McCoy, D. and Engelbrecht, B. (1999): South African Health Review, Briefing Summary, Establishing the District Health System, Health Systems Trust, p.1, (http://www.hst.org.za/sahr).

7. MOH (1998): Egypt-Health Sector Reform Program, Report No. PID5893, The Arab Republic of Egypt, Ministry of Health and Population, p. 1

8. Murray, A. (1990): Rational Approaches to Priority Setting in International Health. Journal of Tropical Medicine, 93: 303-311.

9. Owino, W., Korir, J., Ocholla, P. and Oloo, K. (2000): Decentralisation and Health Systems Development: The Question of Planning, Budgeting and Financial Structures, Abstract, Discussion Paper Institute of Policy Analysis and Research (IPAR).

10. Pailman, C., Schnetler, T., Weyers, T. and Beja, B. (2000): Proposed Implementation Strategy for the Development of A District Health System in the Pedu Metropolitan Health District, Eastern Cape, First Draft Report, p.12.

11. PHILA (1998): The Development of District Health Systems, Department of National Health, Towards A National Health System for South Africa, PHILA Policy Brief, p1.

12. Tjam, S. (1994): Technology Assessment and Transfer for District Health Systems, Division of Strengthening of Health
Services, Geneva: World Health Organization.

13. Wahser, U. (1995): Construction of an Adapted Health Information System at the Example of the District of Kabarole, Uganda, University of Heidelberg, Thesis, (http://www.wahser.de/uwe/DIPLOM/dip0t oc.htm).

14. WHO (1987a): Eighth General Program of Work Covering the Period 1990-1995. "Health for All" Series 10, Geneva: World Health Organization.

15. WHO (1987b): Evaluation of the Strategy for Health for All by the Year 2000. Seventh Report of the Report of the World Health Situation, Vol. 1: Global Review. Geneva: World Health Organization.

16. WHO (1990): Systems of Continuing Education: Priority to District Health Personnel. WHO Technical Report Series No. 803, Geneva: World Health Organization, p.9.

17. WHO (1992): The Hospital in Rural and Urban Districts. WHO Technical Report Series No. 819, Geneva: World Health Organization, p.5-6.

18. WHO (1995a): Renewing the Health for All Strategy, Guidelines Principles and Essential Issues for the Elaboration of A Policy for Equity, Solidarity and Health, Consultation Document, Geneva: World Health Organization, p.1.

19. WHO (1995b): The Work of World Health Organization (WHO) in the Eastern Mediterranean Region. Annual Report of the Regional Director, (www.emro.who.int/rd/AnnualReports/95/ ExecutiveSummary.htm).

20. WHO (1996): The World Population Report 1996: Fighting Disease, Fostering Development, Report of the DirectorGeneral, Geneva: World Health Organization, p.122-130.

21. WHO (1998): District Health Facilities: Guidelines for Development and Operations. WHO Regional Publications, Western Pacific Series No. 22, World Health Organization, p1-5.

22. WHO (2001): Integrated Management of Healthy Settings at the District Level. Report of an Intercountry Consultation Gurgaon, India, WHO Project: ICP HSD001, World Health Organization Regional Office for South-East Asia, New Delhi, p.9. 


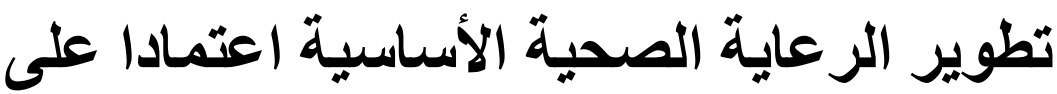



*:أحمد الطوبجى ، **أحمد الحناوى، *عصام المصيلحى ، *على عثمان

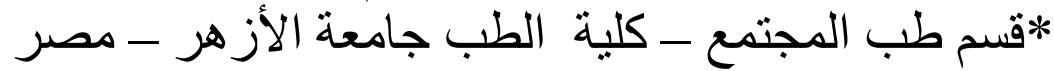
** * إدارة صحة الحضر - وزارة الصحة و السكان - مصر الازهر

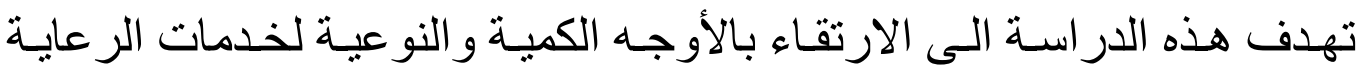

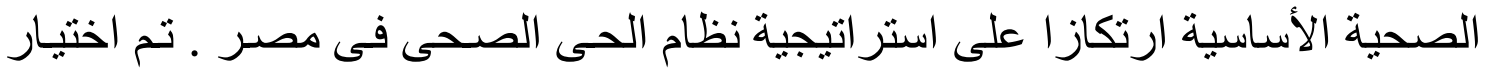


مستشفيات المر اكز بالإضافة الى 201 وحدة رعاية صحية اساسية مختارة عشو ائيا فى 8 محافظات .

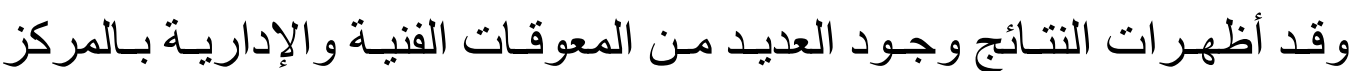

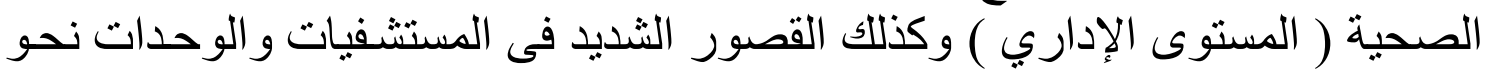
معظم المتغير (ات البحثية التى تم در استها.

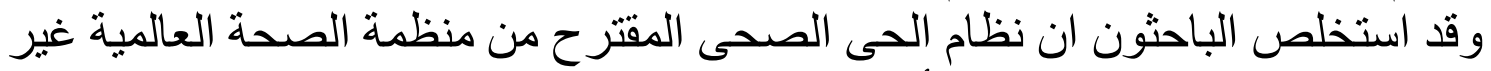

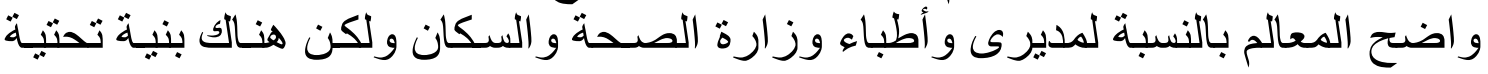
جيدة تسمح بتنفيذه فى مصر ـ ـوقد قام الباحثون بالتحديد الدقيق للعناصر اللازمة لتنفيذ

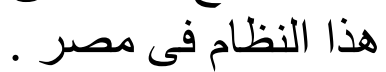

